\author{
GIUSEPPE MAZZA ${ }^{1}$ - DANIELE MARRACCINI ${ }^{1,2}$ - ANDREA LUCCHI ${ }^{2}$ - LEONARDO MARIANELLI $^{1}$ \\ GIUSEPPINO SABBATINI PEVERIERI ${ }^{1}$ - GIOVANNI BOSIO ${ }^{3}$ - EMANUELA GIACOMETTO ${ }^{3}$ - LORENZO RAPA ${ }^{4}$ \\ FABIO CIANFERONI $^{5,6}$ - PIO FEDERICO ROVERSI ${ }^{1}$ - ELISABETTA GARGANI ${ }^{1}$
}

\title{
FIRST RECORD OF RICANIA SPECULUM (WALKER, 1851) (HEMIPTERA RICANIIDAE) FROM VENETO, PIEDMONT AND LATIUM REGIONS AND NEW HOST PLANTS
}

\author{
${ }^{1}$ CREA Research Centre for Plant Protection and Certification, Firenze, Italy. \\ ${ }^{2}$ Department of Agriculture, Food and Environment, University of Pisa, Pisa, Italy. \\ ${ }^{3}$ Settore Fitosanitario e Servizi Tecnico scientifici - Regione Piemonte, Torino, Italy. \\ ${ }^{4}$ Dipartimento di Chimica, Università degli Studi di Torino, Torino Italy. \\ ${ }^{5}$ Natural History Museum of the University of Florence, Zoological Section "La Specola”, Florence, Italy. \\ ${ }^{6}$ Research Institute on Terrestrial Ecosystems, CNR - National Research Council of Italy, Monterotondo (Rome), Italy. \\ Corresponding Author: Giuseppe Mazza, e-mail giuseppe.mazza@crea.gov.it
}

\begin{abstract}
Mazza G., Marraccini D., Lucchi A., Marianelli L., Sabbatini Peverieri G., Bosio G., Giacometto E., Rapa L., Cianferoni F., Roversi P.F., Gargani E. - First record of Ricania speculum (Walker, 1851) (Hemiptera: Ricaniidae) from Veneto, Piedmont and Latium regions and new host plants.
\end{abstract}

The distribution of Ricania speculum (Walker, 1851) (Hemiptera Fulgoromorpha Ricaniidae) in Italy was updated and the species was recorded for the first time in Veneto (2017), Piedmont (2018) and Latium (2018) regions. The occurrence of this species in Sardinia, previously recorded, is here excluded. Moreover, 33 new host plants belonging to 29 families resulted to be attacked by this alien invasive species confirming its outstanding polyphagy.

KEY WorDS: alien invasive species, Fulgoromorpha, Fulgoroidea, Italy, polyphagous insect.

\section{INTRODUCTION}

Ricania speculum (Walker, 1851) (Hemiptera: Fulgoromorpha: Ricaniidae) is an alien invasive species reported for the first time in Europe in 2009 (MAzzA et al., 2014) and in a short time spread across Liguria (MAzzA et al., 2014; Rossi and LuCCHI, 2015) and Tuscany (SILVESTRI, 2017).

This univoltine species feeds and lays eggs on a wide range of host plants and its large polyphagy was immediately highlighted by MAZZA et al. (2014), RossI and LuCCHI (2015), Rossi et al. (2015), LuCCHI and Rossi (2016), LAUDONIA et al. (2017) and SILVESTRI (2017).

The host plants of this species in Italy include important crops (e.g. vines, citrus, olive and other fruit trees) and many ornamental plants (see references above). Sap suction is the main damage reported in addition to injuries, caused by the female which inserts the eggs into the plant tissues with its sharp ovipositor (e.g. RossI et al., 2015; LUCCHI and Rossi, 2016). This ovipositional behavior causes the withering of thin shoots or branch where the eggs were laid, as already mentioned in Rossi et al. (2015). On the contrary, the honeydew production emitted from juveniles and adults seems to do not create damages on host plants (Rossi et al., 2015), but further studies are necessary in the light of the high number of individuals in the new areas of introduction (D. Marraccini, pers. obs.).

Since this exotic planthopper is a real pest for several crops in tropical and subtropical areas (reviewed in MAZZA et al., 2014), the presence in Italy due to its polyphagy is noteworthy, representing a new possible threat for native species and human activities.

Moreover, since PILOtTI et al. (2014) found that the Banana-wilt associated phytoplasma (BWAP) was con- firmed in two specimens of Ricaniidae collected from banana plants, the possible role of $R$. speculum in Italy as a vector of plant pathogens is pivotal and require further studies.

For these reasons, the aim of this note was to update the distribution of $R$. speculum and the list of host plants in Italy.

\section{MATERIALS AND METHODS}

Ricania speculum eggs, nymphs and adults were collected weekly from April to October 2018 in the field, particularly in the municipality of Viareggio (province of Lucca, Tuscany). During the monitoring the host plants and the developmental stages were recorded following Rossi et al. (2015).

We collected data on this species concerning distribution and host plants also in some naturalistic forums on the web ("Forum Natura Mediterraneo", www.naturamediterraneo. com; "Forum Entomologi Italiani", www.entomologi italiani.net; "iNaturalist", www.inaturalist.org).

Plant nomenclature followed the online nomenclatural database "The Plant List" (www.theplantlist.org). The datum for geographical coordinates is WGS84.

\section{RESULTS AND DISCUSSION}

We confirmed the widely spread of Ricania speculum in Tuscany, particularly in the provinces of Massa-Carrara and Lucca, as already highlighted by SILVESTRI (2017), and Pisa (A. Lucchi, pers. obs.).

The report of this Asian planthopper in Sardinia after a 
post in a naturalistic forum (RossI and LUCCHI, 2015) is, on the contrary, a misunderstanding, since F.C. interviewed directly the observer of the "Forum Entomologi Italiani" who explained that he lives in Sardinia, but the record of $R$. speculum regarded Liguria.

For the first time, we reported the presence of this species in Veneto and Piedmont regions. In particular, as regard Veneto, $R$. speculum was found in the Arcella neighborhood, province of Padua (an adult on an orchid plant in August 2017 and few adults inside a building in September 2018: $45^{\circ} 25^{\prime} \mathrm{N} 11^{\circ} 52^{\prime} \mathrm{E}$ ) and in the province of Rovigo, where the species seems already well distributed (two sites in the center of Rovigo: $45^{\circ} 03^{\prime} 47.25^{\prime} \mathrm{N} 11^{\circ} 50$ '37.57'E; $45^{\circ} 04^{\prime} 19.25^{\prime \prime} \mathrm{N} 11^{\circ} 49^{\prime} 33.13^{\prime \prime} \mathrm{E}$ and one site in the municipality of Villadose: $45^{\circ} 04^{\prime} \mathrm{N} 11^{\circ} 53^{\prime} \mathrm{E}$ ). In the Rovigo province several nymphs and adults were observed in July 2018, mainly on Rosa sp. and in September 2018 on Magnolia grandiflora L.

In Piedmont region the species was found in September 2018 on riparian plants around an artificial lake in the municipality of Settimo Torinese $\left(45^{\circ} 08^{\prime} 37.6^{\prime \prime} \mathrm{N} 7^{\circ}\right.$ 43'15.8'E). More than 50 specimens of this alien insect were collected on Acer sp., Crataegus monogyna Jacq., Lythrum salicaria L., Malvaviscus arboreus Cav., Quercus rubra L., Rosa sp., Rubus sp., Salix sp., Typha sp. and Ulmus sp.

In Latium a specimen of $R$. speculum, attracted to lamp during a nocturnal monitoring, was photographed by Falvio Rocchi (www.inaturalist.org) in Rome in the "Parco Regionale dell'Appia Antica" (4152’2.84'N 1230'1.85”E).

Thirty-three new host plants, belonging to 29 families resulted to be attacked by this alien invasive species confirming its highly polyphagy (Table $1 ;$ Fig. I). The list of plants ranges from angiosperms to gymnosperms and, amongst the new host plants, we found several important vegetables, crops and ornamental plants in addiction to wild plants and trees (Table 1). Further investigations on how host plant species nutritional and defensive chemistry affect the subsequent host plant species selection, oviposition and fitness in $R$. speculum, are necessary.

Moreover, eggs of $R$. speculum were found also in a Chestnut tree stakes, Castanea sativa Mill. (Fig. II) in Castiglione Chiavarese (GE) in September 2018 and this could be another important pathway of introduction for this species. Since $R$. speculum lays eggs in several plants, the species could be accidentally introduced in several regions of Italy. Moreover, since Pistoia (Tuscany), the Italian center of nurseries and one of the three most important suppliers of ornamental trees and shrubs in Europe, is close to Lucca, $R$. speculum represents a concern and then needs to be carefully monitored for its possible expansion in all Europe, as already highlighted in Rossi et al. (2015).

\section{ACKNOWLEDGMENTS}

Thanks to Luisa Olivieri for the picture of the Chestnut tree stake in Liguria and Roberto A. Pantaleoni, Clelia Angelini, Elisa Colle, Bianca Gori, Jelena Elena, Giovanna Pavarin, Mirko Guidi, Michele Ratti and Flavio Rocchi (www.inaturalist.org).

Thanks to Francesco Binazzi for the critical reading of the text. The research was supported by the Mipaaft Project "Salvaguardia e valorizzazione del patrimonio olivicolo italiano con azioni di ricerca nel settore della difesa fitosanitaria (SALVAOLIVI)" and in the frame of the Euphresco Project "International Plant Sentinel Network (IPSN)".
Table 1 - Development stages (E-eggs, N-nymphs and A-adults) of Ricania speculum in the new host plants.

\begin{tabular}{|c|c|c|}
\hline FAMILY & GENUS, SPECIES AND AUTHOR & $\begin{array}{c}\text { DeVELOPMENT } \\
\text { STAGE }\end{array}$ \\
\hline Adoxaceae & - Viburnum sp. & $-\mathrm{N}$ \\
\hline Altingiaceae & - Liquidambar styraciflua L. & $-\mathrm{E}, \mathrm{A}$ \\
\hline Anacardiaceae & - Schinus molle L. & $-\mathrm{E}, \mathrm{A}$ \\
\hline Apiaceae & - Daucus carota L. & $-A$ \\
\hline Apocynaceae & $\begin{array}{l}\text { - Hoya } \mathrm{sp} . \\
\text { - Trachelospermum } \\
\text { jasminoides (Lindl.) Lem. }\end{array}$ & $\begin{array}{l}-\mathrm{N} \\
-\mathrm{N}, \mathrm{A}\end{array}$ \\
\hline Bignoniaceae & - Catalpa sp. & $-\mathrm{A}$ \\
\hline Cannabaceae & - Cannabis sativa L. & - E, A \\
\hline Caricaceae & $\begin{array}{l}\text { - Carica } \times \text { pentagona } \\
\text { Heilborn }\end{array}$ & $-A$ \\
\hline Compositae & - Cirsium sp. & $-\mathrm{A}$ \\
\hline Convolvulaceae & - Ipomoea sp. & $-\mathrm{N}$ \\
\hline Cucurbitaceae & $\begin{array}{l}\text { - Cucurbita pepo L. } \\
\text { - Cucumis sativus L. }\end{array}$ & $\begin{array}{l}-\mathrm{N} \\
-\mathrm{A}\end{array}$ \\
\hline Cupressaceae & - Juniperus oxycedrus L. & $-\mathrm{A}$ \\
\hline Cycadaceae & - Cycas revoluta Thunb. & $-\mathrm{N}, \mathrm{A}$ \\
\hline Ericaceae & - Vaccinium $\mathrm{sp}$ & $-\mathrm{N}$ \\
\hline Fagaceae & - Quercus rubra L. & $-\mathrm{A}$ \\
\hline Iridaceae & - Crocosmia sp. & $-\mathrm{N}$ \\
\hline Juglandaceae & $\begin{array}{l}\text { - Carya illinoinensis } \\
\text { (Wangenh.) K.Koch }\end{array}$ & - E, A \\
\hline Lythraceae & - Lythrum salicaria L. & $-\mathrm{A}$ \\
\hline Magnoliaceae & - Magnolia grandiflora L. & $-\mathrm{A}$ \\
\hline Malvaceae & $\begin{array}{l}\text { - Abutilon pictum } \\
\text { (Gillies ex Hook.) Walp. } \\
\text { - Malvaviscus arboreus Cav. }\end{array}$ & $\begin{array}{l}-\mathrm{E}, \mathrm{A} \\
-\mathrm{A}\end{array}$ \\
\hline Myrtaceae & $\begin{array}{l}\text { - Callistemon citrinus } \\
\text { (Curtis) Skeels }\end{array}$ & $-\mathrm{A}$ \\
\hline Oleaceae & - Fraxinus sp. & - E, A \\
\hline Poaceae & $\begin{array}{l}\text { - Hordeum marinum Huds. } \\
\text { - Zea mays L. }\end{array}$ & $\begin{array}{l}-\mathrm{N} \\
-\mathrm{A}\end{array}$ \\
\hline Platanaceae & - Platanus sp. & $-\mathrm{E}, \mathrm{A}$ \\
\hline Solanaceae & - Solanum melongena L. & $-\mathrm{N}$ \\
\hline Tamaricaceae & - Tamarix sp. & $-\mathrm{A}$ \\
\hline Theaceae & - Camellia sp. & $-\mathrm{N}$ \\
\hline Typhaceae & - Typha sp. & $-\mathrm{A}$ \\
\hline Vitaceae & $\begin{array}{l}\text { - Parthenocissus quinquefolia } \\
\text { (L.) Planch. }\end{array}$ & - E, N, A \\
\hline
\end{tabular}

\section{REFERENCES}

Laudonia S., Lucchi A., Rossi E., Viggiani G., 2017 First report on egg-parasitoids of the Asian planthopper Ricania speculum. - Bulletin of Insectology, 70(2): 177180.

Lucchi A., Rossi E., 2016 - The egg-burster in the Asian planthopper Ricania speculum (Walker) (Hemiptera Ricaniidae) - Annals of the Entomological Society of America, 109(1): 121-126.

Mazza G., Pennacchio F., Gargani E., Franceschini I., Roversi P.F., Cianferoni F., 2014 - First report of Ricania speculum (Walker, 1851) in Europe (Hemiptera: Fulgoromorpha: Ricaniidae). - Zootaxa, 3861: 297-300.

Pilotti C.A, Dewhurst C.A., Liefting L.W., Kuniata L., KAKUL T., 2014 - Putative vectors of a phytoplasma associated with Coconut (Cocos nucifera) in Madang Province, Papua New Guinea. - International Journal of Agriculture and Forestry, 4(5): 365-372. 


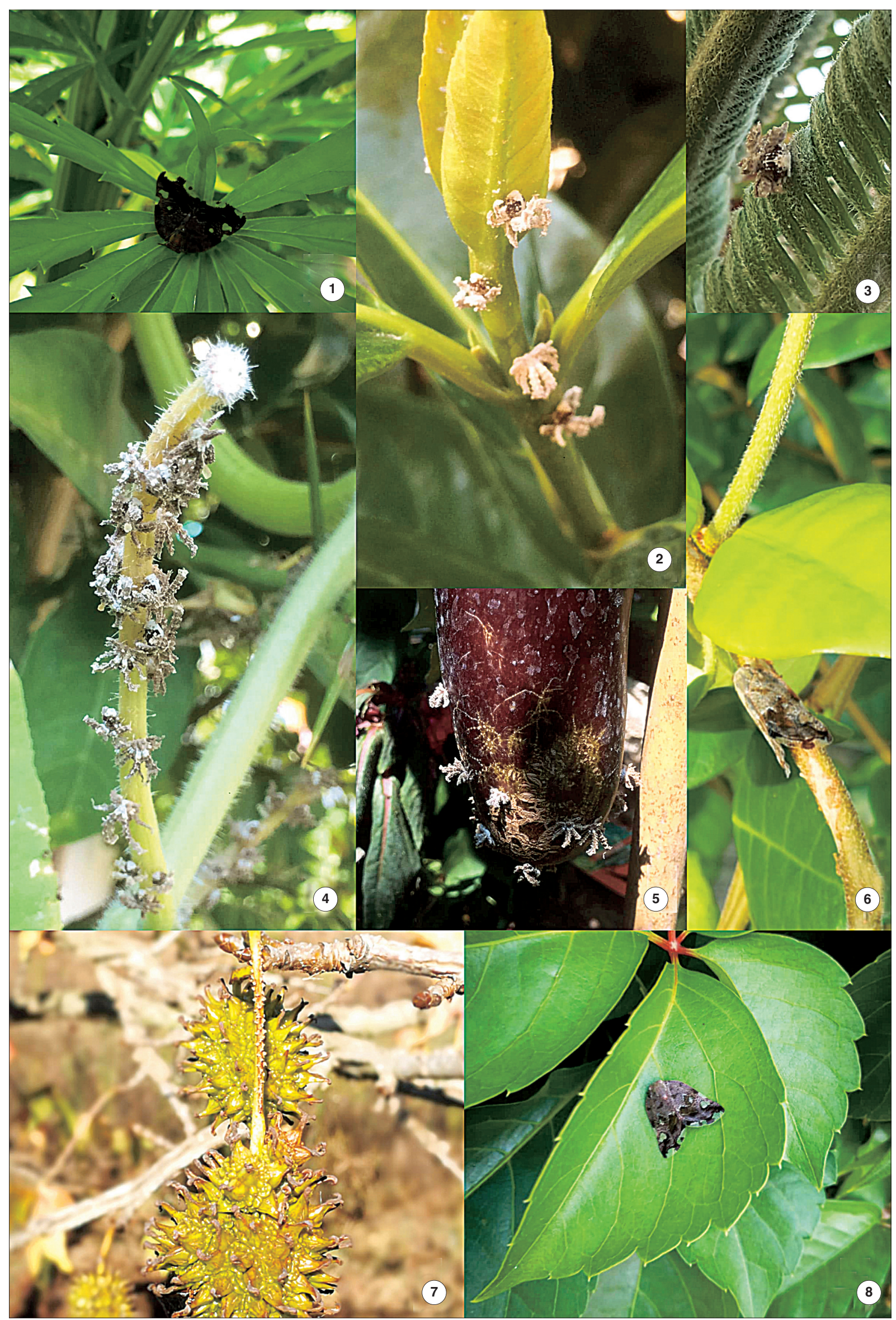

Fig. I - Ricania speculum on new host plants: 1) adult on Cannabis sativa L.;2) nymphs on Viburnum sp.; 3) nymph on Cycas revoluta Thunb.; 4) several nymphs on Cucurbita pepo L.; 5) nymphs on Solanum melongena L.; 6) adult on Trachelospermum jasminoides (Lindl.) Lem.; 7) eggs inserted in a fruit of Liquidambar styraciflua L.; 8) adult on Parthenocissus quinquefolia (L.) Planch. 


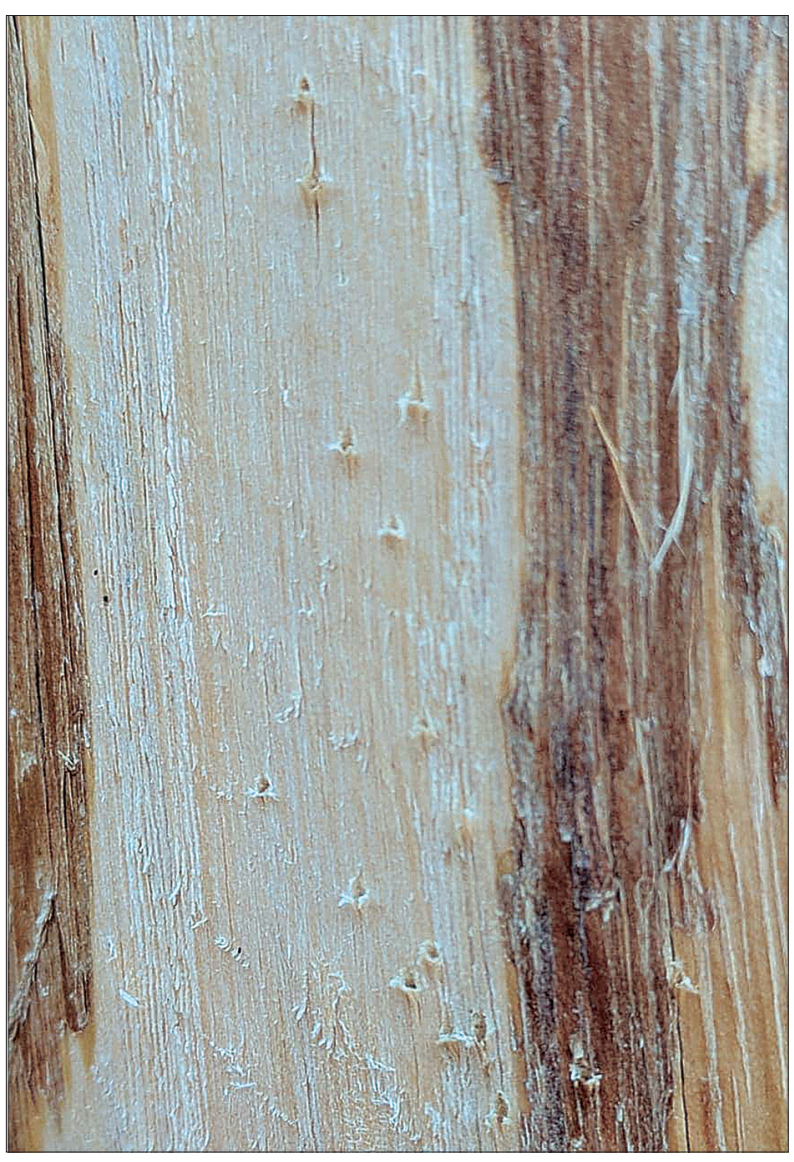

Fig. II - Eggs of Ricania speculum in a Chestnut tree stake.
Rossi E., LucchI A., 2015 - The Asian planthopper Ricania speculum (Walker) (Homoptera Ricaniidae) on several crops in Italy: A potential threat to the EPPO region? OEPP/EPPO Bull., 45: 1-4.

Rossi E., Stroiński A., Lucchi A., 2015 - Egg morphology, laying behavior and record of the host plants of Ricania speculum (Walker, 1851), a new alien species for Europe (Hemiptera: Ricaniidae). - Zootaxa, 4044(1): 93104.

Silvestri S., 2017 - La Problematica delle specie aliene: il caso di studio di Ricania speculum (Walker, 1851), (Hemiptera, Ricaniidae), insetto esotico di recente introduzione in Europa. - Tesi di Laurea, Università degli Studi di Pisa, 87 pp. 